\title{
Michal Pink a kol: Volební mapy České a Slovenské republiky po roce 1993: vzorce, trendy, proměny.
}

Brno: Centrum pro studium demokracie a kultury 2012, 261 s., ISBN 978-80-7325-287-8

\section{Daniel Kunštát ${ }^{1}$}

Volební geografie představuje důležitou subdisciplínu politologie, která na pozadí strukturálních sociodemografických charakteristik obyvatelstva, ale i na základě prostorových specifik, která jsou (nebo mohou být) předobrazem svébytné politické socializace v určitém regionu, nahliží konkrétní území jako specifickou politickou entitu. Zkoumání místně podmíněné volební aktivity odhaluje zvláštní aspekty, vazby a vzájemné souvislosti mezi „mapou“ (tj. vymezenou geografickou oblastî) a „volebním chováním“ místní populace.

$\mathrm{V}$ postkomunistických státech se po úspěšných přechodech $\mathrm{k}$ demokracii postupně obnažovaly zdánlivě zapomenuté vrstvy historických paralel mezi chováním elektorátů a jejich místním ukotvením, které jmenovitě u nás často navazují na volební vzorce z období první (ale i tzv. třetî) republiky. Tato částečná renovace historických stereotypů, zažitých zkušeností a tradic je ovšem přirozeně po desítkách let bez svobodné volební soutěže doplněna, ba v některých momentech i zastíněna, novým socioekonomickým i hodnotovým uspořádáním regionálního politického terénu. Na tuto souběžnou restauraci „starého“ a etablování „nového“ v českém i slovenském prostředí poukázala řada studií již v 90. letech. Autoři knihy Volebni mapy České a Slovenské republiky po roce 1993 se explicitně dovolávají tehdejších závěrů, které se ve své publikaci snaží rozvinout a aktualizovat. S odkazem na Tomáše Kosteleckého vyzdvihují tři důležité předpoklady: a) historicky vzniklé volební mapy, podmíněné silnou tradicí a vlivem sociokulturního prostředí, jsou (pro někoho možná překvapivě) natolik stabilní, že nebyly dramaticky změněny ani $\mathrm{v}$ průběhu relativně krátkého politického a ekonomického vývoje (tj. po roce 1989), b) zatímco $\mathrm{v}$ českém kontextu je možné některé rozdíly vysvětlit ekonomických faktorů, slovenské reálie jsou určovány spíše etnickými, náboženskými a historickými parametry regionů, c) v závislosti na postupném usazování politických stran směřuje české prostředí spíše ke zmenšování regionálních rozdílů, na Slovensku je tomu naopak (s. 7).

Autorský kolektiv v čele s Michalem Pinkem na podkladě určení tzv. územní stabilní volební podpory (resp. v upravené verzi územní supervolební podpory) pečlivě rozkrývá, kde a jak se volí, jak je rozložena koncentrace voličských bází politických stran, tedy které politické formace v různých typech volební soutěže (ve volbách prvého i druhého řádu) získávají na jakém území (okrsku, kraji) větši či menší podporu a jak se tato voličská př́zeň v čase mění. Současně na odpovídajících analytických úrovních poměřují společné rysy, nebo naopak rozdíly v českých zemích a na Slovensku (vědomě jsou z analýz vynechány volby do substátních samosprávných celků s odkazem na to, že $\mathrm{k}$ tomuto tématu existují samostatné rozsáhlé publikace). Pro vysvětlení zvláštností volebního chování autoři adekvátně používají standardní statistické techniky, tj. zejména korelační a regresní analýzy případně jiné metody (Giniho index koncentrace).

Dvě úvodní a zároveň klíčové kapitoly knihy představují elementární kontextuální rámec dané problematiky. Identifikují území stabilní voličské podpory relevantních politických stran

\footnotetext{
${ }^{1}$ PhDr. Daniel Kunštát, Ph.D., Centrum pro výzkum veřejného mínění, Sociologický ústav AV ČR, v.v.i., Jilská 1, 11000 Praha 1, a Vysoká škola CEVRO Institut, Jungmannova 17, 11000 Praha 1. Kontakt: daniel.kunstat@soc.cas.cz
} 
v České a Slovenské republice, a to v zásadě v období od rozdělení společného federativního státu až do roku 2010 (analýzy tedy nezohledňují např́klad výsledky předčasných parlamentních voleb v obou státech v roce 2012, resp. 2013).

Michal Pink a Petr Voda v českých reáliích mapují prostorovou distribuci volebních zisků těch politických stran, které ve sledovaném období uspěly - byt' $v$ některých př́padech nikoliv opakovaně - v hlavním politickém klání ve volbách do Poslanecké sněmovny. Vedle volební účasti se věnují kontinuitě a stabilitě volebního chování a určení míst, ve kterých jednotlivé strany nacházejí volební podporu a nakolik je tato podpora v čase variabilní. Hlavní levicová strana, sociální demokracie, dlouhodobě disponuje regionálně poměrně rovnoměrným rozložením voličské přízně (za významnou mocenskou páteř lze považovat Moravskoslezský kraj), zatímco pravice (ODS/TOP09/US/ODA) boduje v metropolitních, ekonomicky úspěšných regionech Čech (a také $\mathrm{v}$ místech s vyšší volební účastî): „základnim pravidlem je rozdělení na sociálnédemokratickou Moravu a čské Sleasko versus liberálně orientované Cechy" (s. 45). Z tohoto syžetu se vymykají například bašty ČSSD v okrajových částech Středočeského kraje či naopak úspěchy ODS v některých moravských městech (Brno, Zlín). Velmi specifická jsou prostorově rozptýlená silová ohniska KSČM. Strana má systematicky nadprůměrné zisky zejména v oblastech s vy̌̌ší volební abstencí: na severozápadě Čech, na jihu Moravy (Vyškovsko, Znojemsko, Třebíčsko) a v okrajových lokalitách (Jesenicko, Bruntálsko). Pikantní okolností, která bezděky exponuje dramatické změny v posledních letech, je fakt, že autoři v textu určili tři resp. čtyři hlavní silně ukotvené politické subjekty, které tvoří ve sledovaném období ustálenou páteř stranického systému, a sice KSČM, ČSSD a ODS (do r. 2010 i KDU-ČSL).

Tibor Madleňák s Michalem Pinkem analogicky poukazují na trendy voličského chování a regionální odlišnosti volebního chování na Slovensku ve volbách do Národnej rady. Zachycují, jak se v toku dějin vyvijela stabilita nebo naopak jak se územně proměňovala voličská jádra politických stran. Autoři zároveň konstatují, že „Slovensko predstavuje zpobladu volebnej geografie velmi roznôrodú krajinu, kede môžzeme identifikovat' napríklad voličskú qákladñu l'avice jako v mestách, tak aj na vidieku. Podobne je tomu aj vpripade pravice." (s. 87). Stejně jako v českém případě sociální demokracie, také na Slovensku je stranou s dlouhodobě nejrovnoměrněji prostorově rozloženou př́zní především sesterský SMER, který se opírá o hlasy ve dvou klíčových oblastech stabilní volební podpory na periferním severovýchodě a $\mathrm{v}$ menších městech a obcích na pomezí středního a západního Slovenska. Současná dominantní síla levice, ba slovenské politiky vůbec, tedy do jisté míry převzala elektorát v někdejších baštách HZDS (př́p. SNS). Pro reprezentanta reformní liberální politiky a dlouholetého lídra pravice SDKÚ-DS, nacházejícího se na opačném pólu socioekonomické konfliktní linie transformace, je charakteristická (podobně jako u dalších liberálních stran typu $\mathrm{SaS}$ a ANO) velmi stabilní koncentrace hlasů ve vysoce urbanizovaných okresech (Bratislava a okolí, Košice).

Následující kapitola přináší vhled do volebního chování na „transnacionální“ úrovni. Popisuje totiž referenda o vstupu do Evropské unie a volby do Evropského parlamentu. Po výchozím uvedení a komparaci voličských základen autoři pomocí statistických metod poodhalují regionální rozdílnosti v „evropském“ volebním rozhodování. V referendu na Slovensku si všímají nepř́tomnosti relevantního euroskeptického stranického aktéra a s tím související neexistence antagonistických táborů v kampani. To mělo za následek přesvědčivě vysoký souhlas se vstupem do EU, zatímco výsledky v ČR naznačily přece jen vyšší podíl euroskeptických hlasů. Autoři zde vycházejí z konceptu voleb druhého řádu, který předpokládá propad atraktivity vládních stran, nižší volební účast a vysoký podíl hlasů odevzdaných pro menší a neparlamentní strany. V obou 
státech skutečně zaznamenáváme ve volbách do EP podstatně nižší volební účast oproti volbám do národních parlamentů (u nás v roce 2004 i v roce 2009 shodně mírně přesáhla $28 \%$, na Slovensku činila dokonce jen necelých $17 \%$ v r. 2004 a méně než $20 \%$ o pět let později), stejně tak je patrná silnější afinita k „netradičním“ stranám, jakkoliv jejich zisky mnohdy nevedly $\mathrm{k}$ udělení mandátů.

Rozložení podpory ve volbách do EP na Slovensku i v ČR sleduje obdobné trendy jako v „prvořadých“ volbách do dolních komor parlamentů se zřetelným soustředěním jednotlivých voličských táborů do stejných oblastích. V souladu s dř́ive publikovanými studiemi (mj. Lebeda, Linek) autoři zároveň poukazují na možné vysvětlení nízké účasti $\mathrm{v}$ těchto typických „,secondorder elections“, a to v závislosti na podílu vysokoškoláků (resp. na vzdělanostní struktuře), míře urbanizace, průměrném věku a míre nezaměstnanosti (která je v českých zemích nejsilnějším prediktorem, s rostoucí nezaměstnaností zde klesá účast: u úrovně vzdělanosti nalezneme vztah opačný). Pozoruhodná je také identifikace „euroskeptických“ teritorií. Souvislost mezi hlasování v referendu o vstupu do EU a podporou euroskeptických či naopak eurooptimistických stran ukazuje, že alespoň v českých zemích existuje silný vztah mezi účastí v referendu a účastí v evropských volbách, prričemž zejména levicové strany jsou úspěšné v euroskeptickém prostředí (ČSSD, KSČM resp. SMER, SNS či HZDS), centristické a pravicové (např. KDU-ČSL a ODS, resp. SDKÚ a SMK) v prostředí spíše proevropském. Na obou stranách řeky Moravy můžeme vystopovat typicky proevropské oblasti, zejména metropolitní a silně urbanizované regiony (v př́padě Slovenska též príznačně území osídlené mad'arskou menšinou).

V další kapitole Otto Eibl, Michal Pink a Peter Strapáč přibližují slovenskou zvláštnost, totiž institut fakultativních referend neboli celostátních plebiscitů. Zatímco v České republice dosud nebyl přijat prŕislušný prováděcí zákon, na Slovensku je lidové hlasování od počátku živou součástí ústavního pořádku a de facto i politické kultury, jakkoli z řady důvodů součástí nefunkční. Není bez zajímavosti, že šest ze sedmi konaných referend bylo z důvodu nedostatečné účasti prohlášeno za neplatné (onou významnou výjimkou je jen obligatorní referendum o vstupu do EU). A právě volební účast je dle mínění autorů mnohem signifikantnější výpovědí o pozici voličů než samotné výsledky, nebot' povaha referendových hlasování představuje spíše než věcný politický konflikt určitý mobilizační nástroj politických stran (v jednom př́padě i odborů). Referenda zkrátka sloužila parciálním zájmům iniciátorů, at' už ve smyslu přitáhnutí pozornosti k určité straně před volbami nebo ve prospěch nastolení kýženého politického tématu samozřejmě opět s tím, že vyhovuje konkrétním politickým aktérům. Pěkným př́ikladem je referendum z roku 1994 o prokazování prostředků, které byly použity při privatizaci, vyvolané pitoreskním Združením robotníkov Slovenska. Ačkoliv se ho zúčastnilo jen necelých $20 \%$ voličů (z požadovaných $50 \%$ oprávněných), v krátce následujících parlamentních volbách se referendové téma stalo pro tuto stranu erbovním znamením kampaně a událo se cosi překvapivého - „robotníci“ coby volební outsideři uspěli a stali se dokonce součástí vládní koalice. Právě stranický charakter referend, resp. sledování utilitárních zájmů a cílů ze strany politických formací, je také důvod, proč byla drtivá většina referend fakticky zmařena, nebot' se nenaplnila zákonná podmínka volební účasti. Hlasování se často zúčastňují pouze ti, kteří podporují ty politické síly, jež referendum vyvolaly, a sympatizanti jiných politických proudů pak referenda ignorovali, tudíž ,[...] proti sobě nestojí dvě názorové skupiny občanù, ale svou vuili demonstruje pouze jeden tábor. Výsledky blasováni json pak pomèrnè jednoznačné a souzni s doporučením jak blasovat od iniciátorü.“ (s. 145). Údaje o účasti přitom dokládají, že strany, které vypsání referenda vyvolají, jsou schopny mobilizovat více či méně pouze vlastní př́znivce. 
Otto Eibl a Michl Pink se v kapitole zaměřené pro změnu na českou „specialitu“ věnují analýze „druhořadých voleb“ do horní komory Parlamentu ČR. Reflektují senátní volby v letech 1996 až 2010 s důrazem na hledání stranických bašt v jednotlivých volebních okrscích a specifika fungování většinového volebního systému, čímž jejich stat' překračuje kategorie ryzí volební geografie a dotýká se hájemství obecné logiky fungování dvoukolových volebních systémů. Identifikují volební obvody, $\mathrm{v}$ nichž jednotlivé strany získaly mandát vždy, např. ČSSD na Kladně, v Chebu, Domažlicích a Pelhřimově, ODS v Táboře, Českých Budějovicích, Mělníku, a v řadě pražských obvodů, KDU-ČSL v Ústí nad Orlicí, Svitavách a Chrudimi (lidovci jsou navíc kromě svých bašt úspěšní také tam, kde mají tradiční voličské zázemí a kde se zároveň nedaří sociální demokracii, zejména na jihovýchodní Moravě, podobně jako KSČM v okrajových regionech Moravskoslezského a Ústeckého kraje). Za připomenutí stojí také obvody se systematickou podporou kandidátů „neódeesácké“ pravice (opět řada pražských obvodů, Karlovy Vary, Beroun, Plzeň, Hradec Králové). Autoři konstatují, že (do roku 2010) hlavní politické strany, ODS a ČSSD, disponovaly svými obvody, které označují jako „personální bašty“: „Pro levicové kandidáty predstaviji domáci územi predevšim obvody mimo velká mèsta, predev̌̌im Prahu, keteré leží jak v Čechách, tak v nemalé miré na Moravéc (s. 170). Bude ovšem inspirativní sledovat, jak se promění načrtnutá osnova $\mathrm{v}$ souvislosti s nástupem nových politických stran a vzhledem $\mathrm{k}$ marginalizaci (přinejmenším dočasné) dosavadního lídra pravice, ODS.

Vzhledem k časovému záběru knihy rozebírají v předposlední kapitole Michal Pink a Peter Spáč prímé volby hlavy státu výhradně na príkladu Slovenska, v jehož rámci se tento typ voleb mezi lety 1999 až 2010 uskutečnil třikrát. Autoři rozdělují prezidentské kandidáty na pět kategorií: 1) straničtí mainstreamoví středopraví kandidáti disponující podporou hlavně na jihozápadě země a v Košicích; 2) nacionalisticko středoleví opírající se o regiony Kysucka a Pováží, tedy o oblasti, které byly obligátními mocenskými oporami HZDS a SNS a dnes Smeru; 3) křest'anskokonzervativní kandidáti kopírující v zásadě schémata regionálního rozmístění podpory $\mathrm{KDH}$ v periferních severních oblastech s vyšší mírou religiozity (Orava, Spiš, Šariš); 4) občansko středopraví (nestraničtí) kandidáti s doménou v Bratislavském kraji a Banské Bystrici a 5) nezařazení. Podobně jako u politických stran se autoři snaží identifikovat jejich voliče. Sledují proměny volební podpory mezi prvním a druhým kolem a především volební chování vztahují k volbám parlamentním ( $v$ prvním kole se valná část voličů rozhoduje jednoznačně podle stranického klíče, když v této fázi existuje jasná korelace s parlamentními stranickými volbami). Konstatují silnou bipolarizaci slovenské společnosti (nejen z územního hlediska), která se krystalicky projevuje zejména ve druhém kole voleb a dobře byla vidět např́ílad u soubojů Mečiara se Schusterem i Gašparovičem (s průkaznou prostorovou ilustrací transferu propadlých hlasů pravice a středu z prvního kola $\mathrm{k}$ pozdější hlavě státu v kole druhém).

Poslední část publikace představuje logický shrnující pandán k úvodním kapitolám knihy. Text Michala Pinka a Petra Vody sumarizuje obecné trendy v prostorových vzorcích volebního chování v parlamentních volbách vČeské republice a na Slovensku. Autoři zde ukazují, vycházejíc z klasického konceptu cleavages, vzájemné vazby mezi sociodemografickými charakteristikami regionu a volební podporou politických stran, identifikují silné sociální proměnné a významnost jejich vlivu a dokládají, že v obou zemích existuje „silná závislost volební podpory stran na charakteristikách společnosti“. Třídní štěpící linie je silnější v České republice (stejně tak je zde více patrná „inglehartovská“ linie postmaterialismus - materialismus), zatímco na Slovensku je ústřední linií konflikt centraa periferie. Zkrátka a dobře, prrinášejí vynikající materiál ke studiu sociologie politiky - nikoliv na základě „měkkých“ empirických 
výzkumů (voličů či straníků), ale na základě „tvrdého“, na statistických datech založeného rozboru sociálních determinant daného politického prostoru a jejich účinku na distribuci hlasů. Oba tyto úhly pohledu se přitom vzájemně takřka ideálně doplňují. Pisatelé v této souvislosti upozorňují např́iklad na materialisticko-venkovské založení KSČM nebo na fakt, že u protestních stran se vliv sociální a ekonomické struktury voličstva jeví jako velmi marginální, nebot' jejich politická lukrativnost je dána jinými předpoklady.

Kolektiv autorů ukazuje, kolik užitečných a na první pohled ne zcela zřejmých informací lze získat zkoumáním „,volebních map“. V knize totiž na této platformě nastiňují vskutku plastický obraz v nejširším smyslu sociálního určení volebního chování. Poukazují na mnohé divergence, ale i řadu shodných prvků, mezi jinými na dominantní úlohu socioekonomické třídní konfliktní linie levice - pravice, ale i na štěpení město - venkov, do určité míry i centrum - periferie (Čechy - Morava, na Slovensku sever - jih či Praha/Bratislava - „zbytek“ země). Explanační hodnota práce je přirozeně limitována vymezeným časovým záběrem do roku 2010, pohybuje se tedy v kontextu dost možná zlatého věku stabilizovaného stranického systému. Přinejmenším na české politické scéně tedy nevysvětluje (a vysvětlovat ani nemůže) rekonfiguraci mocenských těžišt' v souvislosti s aktuální částečnou dekonstrukcí stranického spektra, metamorfózu volebních schémat voličů a vzestup protestních hnutí. Bez ohledu na to ale máme co do činění s výbornou, metodologicky velmi sofistikovanou komparativní přriručkou ke studiu vývoje, komplementarit i diferencí ve volebním chování v nástupnických státech bývalé federace. 